\title{
Hubungan Dukungan Keluarga dengan Kemandirian Lansia dalam Memenuhi Aktivitas Kehidupan Sehari-hari di Desa Tonusu Kecamatan Pamona Puselemba Kabupaten Poso
}

\section{Relationship between Family Support and Independence of the Elderly in Fulfilling Daily Life Activities in Tonusu Village, Pamona Puselemba District, Poso Regency}

\author{
Fany Lairin Djala ${ }^{1 *}$, Arwin Gugu ${ }^{2}$ \\ 1,2 Program Studi S1 Keperawatan STIKES Husada Mandiri Poso, Sulawesi Tengah, Indonesia \\ *Corresponding author \\ Email: fanylairin@gmail.com
}

Keyword :

Family support,

Elderly

independence

\begin{abstract}
A b stract
Background: Elderly is someone aged 60 years and over. The elderly experience changes in the form of decreased organ function so that the elderly have difficulty in fulfilling daily activities. Elderly independence in daily activities can be measured by the Katz Index. In this era of globalization, families are busy with their respective jobs so that they pay less attention to or provide support to the elderly. Objective: to determine the relationship between family support and independence of the elderly in fulfilling activities of daily life in Tonusu Village, Pamona Puselemba District, Poso Regency. Methods: The type of research used is descriptive analytic with a cross-sectional approach. The sample used is 50 respondents using simple random sampling technique. Data collection was done by using a questionnaire. Results: showed that there was a relationship between emotional support and the independence of the elderly in fulfilling daily activities with a $p$ value = 0.000 , there was a relationship between instrumental support and the independence of the elderly in fulfilling daily activities ( $p$ value $=0.000$ ), there was a relationship between assessment support and the independence of the elderly. in fulfilling daily activities ( $p$ value = 0.002), there is a relationship between informational support and the independence of the elderly in fulfilling daily activities ( $p$ value $=0.000$ ), Conclusion: It can be concluded that there is a relationship between family support and elderly independence in fulfilling activities of daily life in Tonusu Village, Pamona Puselemba Subdistrict, Poso Regency
\end{abstract}

Kata kunci :

Dukungan keluarga,

Kemandirian lansia

\begin{abstract}
A B S T R A K
Latar Belakang: Lansia merupakan seseorang yang berusia 60 tahun keatas atau lebih. Lansia mengalami perubahan berupa penurunan fungsi organ tubuh sehingga lansia mengalami kesulitan dalam memenuhi aktivitas sehari-hari. Kemandirian lansia dalam aktivitas sehari-hari dapat diukur dengan Indeks Katz. Di era globalisasi ini keluarga disibukkan oleh pekerjaan mereka masing- masing sehingga kurang memperhatikan atau memberi dukungan kepada lansia. Tujuan: mengetahui hubungan dukungan keluarga dengan kemandirian lansia dalam memenuhi aktivitas kehidupan sehari-hari di Desa Tonusu Kecamatan Pamona Puselemba Kabupaten Poso. Metode: Jenis penelitian yang digunakan adalah deskriptif analitik dengan pendekatan cross-sectional. Sampel yang digunakan berjumlah 50 responden dengan menggunakan tehnik Simple random sampling. Pengumpulan data dilakukan dengan menggunakan kuesioner. Hasil penelitian menunjukkan adanya hubungan antara dukungan emosional dengan kemandirian lansia dalam memenuhi aktivitas sehari hari dengan nilai $\mathrm{p}=0,000$, ada hubungan antara dukungan instrumental dengan kemandirian lansia dalam memenuhi aktivitas sehari hari (nilai $\mathrm{p}=0,000$ ), ada hubungan antara dukungan penilaian dengan kemandirian lansia dalam memenuhi aktivitas sehari hari (nilai $\mathrm{p}=0,002$ ), ada hubungan antara dukungan informasional dengan dengan kemandirian lansia dalam memenuhi aktivitas sehari hari
\end{abstract}


(nilai $\mathrm{p}=0,000)$. Kesimpulan: Dapat disimpulkan bahwa ada hubungan antara dukungan keluarga dengan kemandirian lansia dalam memenuhi aktivitas kehidupan sehari-hari di Desa Tonusu Kecamatan Pamona Puselemba Kabupaten Poso

How To Cite : Djala, F.L., \& Gugu, A. 2021. Hubungan Dukungan Keluarga dengan Kemandirian Lansia dalam Memenuhi Aktivitas Kehidupan Sehari-hari di Desa Tonusu Kecamatan Pamona Puselemba Kabupaten Poso. Journal of Islamic Medicine. 5(2),114-124.

https://doi.org/10.18860/jim.v5i2.13262

Copyright (C) 2021

\section{LATAR BELAKANG}

Proses penuaan merupakan suatu proses alamiah, tidak dapat dicegah dan merupakan hal wajar dialami oleh orang dikarunia umur panjang. Orang-orang ini berharap akan menjalani hidup dengan tetap sehat, tenang, damai, penuh kasih sayang serta menikmati masa tuanya bersama keluarga tercinta. ${ }^{1}$

Peningkatan jumlah populasi lansia saat ini menjadi isu penting bagi dunia. Berdasarkan data World Health Organization (WHO) pada tahun 2015 terdapat 901 juta jumlah lansia yang terdiri dari jumlah populasi global. Pada tahun 2015-2030 jumlahnya diproyeksikan akan. tumbuh sekitar 56\% menjadi 1,4 milyar. Populasi orang berusia di atas 65 tahun sedunia sekarang berada ada 617 juta orang. Angka tersebut setara dengan 8,5 persen dari jumlah seluruh penduduk planet ini. Namun demikian, sebelum tahun 2050, jumlah penduduk lanjut usia meningkat menjadi 1,6 miliar orang setara dengan hampir $17 \%$ penduduk dunia saat itu. ${ }^{2}$

Penduduk lanjut usia di Indonesia pada tahun 2007 berjumlah 18,7 juta jiwa selanjutnya pada tahun 2010 meningkat menjadi 23,9 juta jiwa (9,77 persen). Pada tahun 2020 diprediksikan jumlah lanjut usia mencapai 28,8 juta jiwa (11,34 persen). ${ }^{3}$

Secara biologi, lanjut usia mengalami proses penuaan secara terus menerus yang ditandai dengan menurunnya daya fisik terhadap penyakit. Penurunan fisik ini dapat dilihat terutama pada kemampuan lanjut usia untuk melakukan aktivitas kehidupan seharihari seperti berpakaian, buang air besar atau kecil, makan, minum, berjalan, tidur, dan mandi. Dari kemampuan melakukan aktivitas tersebut dapat dinilai apakah lanjut usia mandiri atau tergantung pada orang lain. Mandiri dalam melakukan aktivitas kehidupan sehari-hari (Activities of Daily living=ADL) adalah kebebasan untuk bertindak, tidak tergantung pada pihak lain dalam merawat diri maupun dalam beraktivitas sehari-hari. Semakin mandiri status fungsional lansia maka kemampuan untuk bertahan terhadap serangan penyakit akan semakin baik. Sebaliknya lansia yang menunjukkan ketergantungan akan rentan terhadap serangan penyakit. ${ }^{4}$

Dukungan keluarga yang optimal mendorong kesehatan para lansia meningkat, selain itu kegiatan harian para lansia menjadi teratur dan tidak berlebihan. Bagian dari dukungan sosial adalah cinta dan kasih sayang yang harus dilihat secara terpisah sebagai bagian asuhan dan perhatian dalam fungsi efektif keluarga. ${ }^{5}$ Namun kenyataanya banyak di temukan penurunan kemandirian pada lansia yang tinggal dengan keluarga, hal ini karena banyak keluarga lansia sibuk dengan pekerjaan mereka masing-masing di samping itu meningkatnya kebutuhan ekonomi membuat semua anggota keluarga bekerja diluar rumah, sehingga menyebabkan keluarga yang mempunyai lansia kurang memperhatikan atau memberi dukungan yang optimal kepada lansia. ${ }^{6}$

Berdasarkan data yang diperoleh peneliti, jumlah lansia di wilayah kerja puskesmas Tonusu cukup besar yaitu sebanyak 100 orang dari jumlah seluruh penduduk yaitu 560 jiwa. Berdasarkan hasil wawancara singkat dengan 3 lansia mengatakan tidak bisa melakukan aktivitas misalnya makan jika tidak dibantu oleh keluarga padahal kondisi fisik mereka masih kuat. Ada juga 2 orang lansia yang mengatakan bahwa mereka kurang mendapatkan dukungan dari anggota 
keluarga dalam hal melakukan kegiatan sehari hari.

Berdasarkan latar belakang diatas, peneliti tertarik ingin melakukan penelitian untuk mengetahui "hubungan dukungan keluarga dengan kemandirian lansia dalam memenuhi aktivitas kehidupan sehari-hari di Desa Tonusu Kecamatan Pamona Puselemba Kabupaten Poso"

\section{METODE}

Desain penelitian yang digunakan dalam penelitian ini adalah analitik korelasi dengan menggunakan pendekatan cross sectional. Populasi dalam penelitian ini adalah lansia yang ada di Desa Tonusu Kecamatan Pamona Puselemba Kabupaten Poso berjumlah 10 orang dengan jumlah sampel sebesar 50 responden. Penentuan sampel dengan menggunakan teknik simple random sampling dengan kriteria inklusi yaitu lansia yang berusia 60-74 tahun, bertempat tinggal di desa Tonusu, tinggal bersama keluarga, bersedia menjadi responden. Penelitian dilaksanakan pada Bulan Maret Tahun 2021. Data diperoleh dengan menggunakan kuesioner untuk dukungan keluarga yang terdiri dari dukungan emosional, dukungan instrumental, dukungan penilaian, dukungan informasional dan Indeks Katz yang merupakan alat ukur digunakan untuk mengukur tingkat kemandirian lansia yang terdiri dari aktivitas mandi, berpakaian, ke kamar kecil, berpindah, kontinen dan aktivitas makan. Data dianalisis dengan uji statistik yaitu Chi-Square dengan menggunakan program SPSS.

\section{HASIL PENELITIAN}

\section{Karakteristik Responden}

a. Jenis Kelamin

Tabel 1. Distribusi Frekuensi Responden Berdasarkan Jenis Kelamin

\begin{tabular}{ccc}
\hline Jenis Kelamin & F & \% \\
\hline Laki-laki & 21 & 42 \\
Perempuan & 29 & 58 \\
\hline Total & 50 & 100 \\
\hline
\end{tabular}

Sumber data primer, 2021

Berdasarkan Tabel 1, distribusi frekuensi jenis kelamin sebagian besar responden berjenis kelamin perempuan yaitu sebanyak 29 responden (58\%). Dan yang berjenis kelamin laki-laki sebanyak 21 responden $(42 \%)$.

b. $\underline{\text { Umur }}$

Tabel 2. Distribusi Frekuensi Berdasarkan Umur Responden

\begin{tabular}{ccc}
\hline Umur & F & \% \\
\hline $60-64$ & 22 & 44 \\
$65-69$ & 24 & 48 \\
$70-74$ & 4 & 8 \\
\hline Total & 50 & 100
\end{tabular}

Berdasarkan Tabel 2, distribusi frekuensi umur menunjukkan bahwa sebagian besar reponden berumur 65-69 yaitu sebanyak 24 reponden (48\%) dan sebagian kecil yang berumur 70-74 sebanyak 4 reponden (8\%) selebihnya yang berumur 60-64 sebanyak 22 reponden $(44 \%)$. 
Djala, dkk.

c. Pendidikan

Tabel 3. Distribusi Frekuensi Berdasarkan Pendidikan Responden

\begin{tabular}{ccc}
\hline Pendidikan & F & \% \\
\hline SD & 7 & 14 \\
SMP & 20 & 40 \\
SMA & 20 & 40 \\
SARJANA & 3 & 6 \\
\hline Total & 50 & 100
\end{tabular}

Sumber data primer, 2021

Berdasarkan Tabel 3, distribusi frekuensi pendidikan menunjukkan bahwa sebagian besar responden berpendidikan SMA dan SMP yaitu masing-masing 20 responden $(40 \%)$ dan sebagian kecil yang berpendidikan sarjana sebanyak 3 responden $(6 \%)$ selebihnya berpendidikan SD sabanyak 7 responden (14\%).

\section{Analisa Univariat}

a. Dukungan Keluarga

1) Dukungan Emosional

Tabel 4. Distribusi Frekuensi Dukungan Emosional

\begin{tabular}{ccc}
\hline Dukungan Emosional & F & \% \\
\hline Baik & 36 & 72 \\
Kurang & 14 & 28 \\
\hline Total & 50 & 100 \\
\hline
\end{tabular}

Sumber data primer, 2021

Berdasarkan Tabel 4, distribusi frekuensi dukungan emosional menunjukkan bahwa sebagian besar responden menerima dukungan emosional yang baik yaitu sebanyak 36 responden (72\%) dan sebagian kecil yang kurang sebanyak 14 responden $(28 \%)$.

2) Dukungan Instrumental

Tabel 5. Distribusi Frekuensi Dukungan Instrumental

\begin{tabular}{ccc}
\hline Dukungan Instrumental & F & \% \\
\hline Baik & 37 & 74 \\
Kurang & 13 & 26 \\
\hline Total & 50 & 100 \\
\hline
\end{tabular}

Sumber data primer, 2021

Berdasarkan Tabel 5, distribusi frekuensi dukungan instrumental menunjukkan bahwa sebagian besar responden menerima dukungan instrumental yang baik yaitu sebanyak 37 responden (74\%) dan sebagian kecil yang kurang sebanyak 13 responden $(26 \%)$.

3) Dukungan Penilaian

Tabel 6. Distribusi Frekuensi Dukungan Penilaian

\begin{tabular}{ccc}
\hline Dukungan Penilaian & F & \% \\
\hline Baik & 39 & 78 \\
Kurang & 11 & 22 \\
\hline Total & 50 & 100
\end{tabular}

Sumber data primer, 2012

Berdasarkan tabel distribusi 6 frekuensi dukungan penilaian menunjukkan bahwa sebagian besar responden menerima dukungan penilaian yang baik yaitu sebanyak 39 responden $(78 \%)$ dan sebagian kecil yang kurang sebanyak 11 responden (22\%). 
4) Dukungan Informasional

Tabel 7. Distribusi Frekuensi Dukungan Informasional

\begin{tabular}{ccc}
\hline Dukungan Informasional & F & $\%$ \\
\hline Baik & 37 & 74 \\
Kurang & 13 & 26 \\
\hline Total & 50 & 100 \\
\hline Sumber data primer, 2021 & &
\end{tabular}

Berdasarkan Tabel 7, distribusi frekuensi dukungan informasional menunjukkan bahwa sebagian besar responden menerima dukungan Informasional yang baik yaitu sebanyak 37 responden (74\%) dan sebagian kecil yang kurang sebanyak 13 responden $(26 \%)$.

b. Kemandirian Lansia

Tabel 8. Distribusi Frekuensi Kemandiran Lansia

\begin{tabular}{ccc}
\hline Kemandirian Lansia & F & \% \\
\hline Mandiri & 29 & 58 \\
Tidak Mandiri & 21 & 42 \\
\hline Total & 50 & 100
\end{tabular}

Berdasarkan Tabel 8, distribusi frekuensi kemandirian lansia menunjukkan bahwa sebagian besar responden mandiri dalam melakukan aktivitas sehari-hari yaitu sebanyak 29 responden (58\%), dan sebagian kecil yang tidak mandiri sebanyak 21 responden $(42 \%)$.

\section{Analisa bivariat}

a. Dukungan Emosional dengan Kemandirian Lansia

Tabel 9. Dukungan Emosional Dengan Tingkat Kemandirian Lansia

\begin{tabular}{|c|c|c|c|c|c|c|c|}
\hline \multirow{3}{*}{$\begin{array}{l}\text { Dukungan } \\
\text { Emosional }\end{array}$} & \multicolumn{4}{|c|}{ Kemandirian Lansia } & \multirow{2}{*}{\multicolumn{2}{|c|}{ Total }} & \multirow{6}{*}{$\begin{array}{c}p \text {-value } \\
0,000\end{array}$} \\
\hline & \multicolumn{2}{|c|}{ Mandiri } & \multicolumn{2}{|c|}{ Tidak Mandiri } & & & \\
\hline & $\mathrm{f}$ & $\%$ & $\mathrm{f}$ & $\%$ & $\mathrm{f}$ & $\%$ & \\
\hline Baik & 27 & 54 & 9 & 18 & 36 & 72 & \\
\hline Kurang & 2 & 4 & 12 & 24 & 14 & 28 & \\
\hline Total & 29 & 54 & 21 & 42 & 50 & 100 & \\
\hline
\end{tabular}

Berdasarkan hasil analisis bivariat, menunjukkan bahwa dari 36 responden yang menerima dukungan emosional baik dan mandiri dalam melakukan aktivitas sehari-hari yaitu sebanyak 27 responden (54\%), dan tidak mandiri berjumlah 9 responden (18\%). Sedangkan dari 14 responden yang menerima dukungan emosional kurang dan mandiri dalam melakukan aktivitas sehari-hari yaitu sebanyak 2 responden (4\%), dan tidak mandiri sebanyak 12 responden (24\%).

Berdasarkan hasil uji chi square diperoleh nilai $\mathrm{p}=0,000$ lebih kecil dari nilai $\alpha=$ 0,05. Dari analisis tersebut dapat diartikan bahwa Ho ditolak dan Ha diterima atau ada hubungan antara dukungan emosional dengan kemandirian lansia dalam memenuhi aktivitas kehidupan sehari-hari.

b. Dukungan Instrumental dengan Kemandirian Lansia

Tabel 10. Dukungan Instrumental Dengan Kemandirian Lansia

\begin{tabular}{|c|c|c|c|c|c|c|c|}
\hline \multirow{3}{*}{$\begin{array}{l}\text { Dukungan } \\
\text { Instrumental }\end{array}$} & \multicolumn{4}{|c|}{ Kemandirian Lansia } & \multirow{2}{*}{\multicolumn{2}{|c|}{ Total }} & \multirow[b]{3}{*}{$p$-value } \\
\hline & \multicolumn{2}{|c|}{ Mandiri } & \multicolumn{2}{|c|}{ Tidak Mandiri } & & & \\
\hline & $\mathrm{f}$ & $\%$ & $\mathrm{f}$ & $\%$ & $\mathrm{f}$ & $\%$ & \\
\hline Baik & 27 & 54 & 10 & 20 & 37 & 74 & 0,000 \\
\hline Kurang & 2 & 4 & 11 & 22 & 13 & 26 & \\
\hline Total & 29 & 58 & 21 & 42 & 50 & 100 & \\
\hline
\end{tabular}


Sumber data primer, 2021

Berdasarkan hasil analisis bivariat, menunjukkan bahwa dari 37 responden yang menerima dukungan instrumental baik dan mandiri dalam melakukan aktivitas sehari-hari yaitu sebanyak 27 responden (54\%), dan tidak mandiri berjumlah 10 responden (20\%). Sedangkan dari 13 responden yang menerima dukungan instrumental kurang dan mandiri dalam melakukan aktivitas sehari-hari yaitu sebanyak 2 responden (4\%), dan tidak mandiri sebanyak 11 responden (22\%).

Berdasarkan hasil uji chi square diperoleh nilai $\mathrm{p}=0,000$ lebih kecil dari nilai $\alpha=$ 0,05. Dari analisis tersebut dapat diartikan bahwa Ho ditolak dan Ha diterima atau ada hubungan antara dukungan instrumental dengan kemandirian lansia dalam memenuhi aktivitas kehidupan sehari-hari

c. Dukungan Penilaian dengan Kemandirian Lansia

Tabel 11 Dukungan Penilaian dengan Kemandirian Lansia

\begin{tabular}{|c|c|c|c|c|c|c|c|}
\hline \multirow{3}{*}{$\begin{array}{l}\text { Dukungan } \\
\text { Penilaian }\end{array}$} & \multicolumn{4}{|c|}{ Kemandirian Lansia } & \multirow{2}{*}{\multicolumn{2}{|c|}{ Total }} & \multirow{6}{*}{$\begin{array}{c}p- \\
\text { value } \\
0,002\end{array}$} \\
\hline & \multicolumn{2}{|c|}{ Mandiri } & \multicolumn{2}{|c|}{ Tidak Mandiri } & & & \\
\hline & $\mathrm{f}$ & $\%$ & $\mathrm{f}$ & $\%$ & $\mathrm{f}$ & $\%$ & \\
\hline Baik & 27 & 54 & 12 & 24 & 39 & 78 & \\
\hline Kurang & 2 & 4 & 9 & 18 & 11 & 22 & \\
\hline Total & 29 & 58 & 21 & 42 & 50 & 100 & \\
\hline
\end{tabular}

Berdasarkan hasil analisis bivariat, menunjukkan bahwa dari 39 responden yang menerima dukungan penilaian baik dan mandiri dalam melakukan aktivitas sehari-hari yaitu sebanyak 27 responden (54\%), dan tidak mandiri berjumlah 12 responden (24\%). Sedangkan dari 11 responden yang menerima dukungan penilaian kurang dan mandiri dalam melakukan aktivitas sehari-hari yaitu sebanyak 2 responden (4\%), dan tidak mandiri sebanyak 9 responden (18\%).

Berdasarkan hasil uji chi square diperoleh nilai $\mathrm{p}=0,002$ lebih kecil dari nilai $\alpha=$ 0,05. Dari analisis tersebut dapat diartikan bahwa Ho ditolak dan Ha diterima atau ada hubungan antara dukungan penilaian dengan kemandirian lansia dalam memenuhi aktivitas kehidupan sehari-hari.

d. Dukungan Informasional dengan Kamandirian Lansia

Tabel 12. Dukungan Informasional Dengan Kemandirian Lansia

\begin{tabular}{|c|c|c|c|c|c|c|c|}
\hline \multirow{3}{*}{$\begin{array}{l}\text { Dukungan } \\
\text { Penilaian }\end{array}$} & \multicolumn{4}{|c|}{ Kemandirian Lansia } & \multirow{2}{*}{\multicolumn{2}{|c|}{ Total }} & \multirow{6}{*}{$\begin{array}{c}p \text {-value } \\
0,000\end{array}$} \\
\hline & \multicolumn{2}{|c|}{ Mandiri } & \multicolumn{2}{|c|}{ Tidak Mandiri } & & & \\
\hline & $\mathrm{f}$ & $\%$ & $\mathrm{f}$ & $\%$ & $f$ & $\%$ & \\
\hline Baik & 27 & 54 & 10 & 20 & 37 & 74 & \\
\hline Kurang & 2 & 4 & 11 & 22 & 13 & 26 & \\
\hline Total & 29 & 58 & 21 & 42 & 50 & 100 & \\
\hline
\end{tabular}

Berdasarkan hasil analisis bivariat, menunjukkan bahwa dari 37 responden yang menerima dukungan informasional baik dan mandiri dalam melakukan aktivitas seharihari yaitu sebanyak 27 responden (54\%), dan tidak mandiri berjumlah 10 responden (20\%). Sedangkan dari 13 responden yang menerima dukungan informasional kurang dan mandiri dalam melakukan aktivitas sehari-hari yaitu sebanyak 2 responden (4\%), dan tidak mandiri sebanyak 11 responden (22\%).

Berdasarkan hasil uji chi square diperoleh nilai $\mathrm{p}=0,000$ lebih kecil dari nilai $\alpha=$ 0,05. Dari analisis tersebut dapat diartikan bahwa Ho ditolak dan Ha diterima atau ada hubungan antara dukungan informasional dengan kemandirian lansia dalam memenuhi aktivitas kehidupan sehari-hari. 


\section{PEMBAHASAN}

\section{Hubungan Dukungan Emosional terhadap Kemandirian Lansia dalam Memenuhi Aktivitas Kehidupan Sehari- Hari}

Pada penelitian ini berdasarkan hasil uji statistik dengan menggunakan ChiSquare diperoleh adanya hubungan antara dukungan emosional terhadap kemandirian lansia dalam memenuhi aktivitas kehidupan sehari-hari.

Penelitian ini didukung oleh penelitian dari lain yang melakukan penelitian tentang hubungan dukungan keluarga dengan kemampuan aktifitas sehari-hari lansia di Kota Semarang bahwa dari 98 responden, $63,2 \%$ keluarga yang dukungan emosional baik kemampuan aktifitas sehari-hari lansia mandiri dan 36,8\% dukungan emosional kurang baik kemampuan aktifitas sehari-hari lansia ketergantungan. ${ }^{7}$

Dukungan emosional merupakan dukungan yang diberikan kepada individu sehingga indiviu merasa nyaman, merasa dicintai saat mengalami depresi, bantuan dalam bentuk semangat, empati, rasa percaya, perhatian sehingga individu yang menerimanya merasa berharga. ${ }^{8}$

Dukungan emosional yang diberikan kepada lansia berupa kepedulian anggota keluarga terhadap kemandirian lansia dalam aktivitas sehari-hari. Lansia tidak hanya membutuhkan dukungan secara fisik saja tetapi hubungan emosional antar anggota keluarga akan sangat mendukung lansia dalam mempertahankan kemandiriannya. Dukungan emosional terutama didapatkan dari keluarga, bahwa kasih sayang dari anggota keluarga kepada anggota keluarga yang lain, memberikan penghargaan terhadap kehidupan keluarga terutama berkaitan dengan persepsi dan perhatian terhadap kebutuhan sosio emosional para anggota keluarga. ${ }^{9}$

Salah satu fungsi keluarga adalah fungsi asih dimana antar anggota keluarga saling memberikan kasih sayang dan rasa aman, memberikan perhatian dan kehangatan terutama pada lansia yang mengalami penurunan kemampuan fisik. Dalam teori kepribadian, menyatakan bahwa lansia (yang usianya diatas 60 tahun) merasa hidup mereka sudah dekat dengan akhir hayat dan pada masa ini kasih sayang dari lingkup keluarga terdekat merupakan kenikmatan tersendiri. Hal ini menunjukkan bahwa perawatan oleh keluarga akan menguntungkan tidak hanya secara fisik tapi juga psikologis lansia. ${ }^{10}$

Keluarga mempunyai empat peran utama dalam membantu kemandirian lansia, salah satunya adalah motivator yaitu dengan memberikan dukungan secara emosional, yang membuat lansia punya motivasi untuk dapat melakukan aktivitasnya semandiri mungkin.

Dari hasil penelitian ini diperoleh bahwa sebagian besar lansia menerima dukungan emosional yang baik dari anggota keluarga sehingga membuat lansia mandiri dalam melakukan aktivitas sehari hari antara lain mandi, mengganti pakaian sendiri serta makan dan minum secara mandiri. Dukungan keluarga yang diberikan antara lain memberikan pujian kepada lansia saat lansia bisa mandi sendiri. Selain itu keluarga juga memberikan kepercayaan kepada lansia untuk dapat melakukan aktivitas sehari hari secara mandiri.

Pada penelitian ini juga diperoleh lansia yang mengalami dukungan keluarga kurang namun memiliki kemandirian dalam melakukan aktivitas sehari hari. Hal ini karena karakteristik responden lansia sebagian besar berusia 60-65 tahun (52.9\%) dimana pada usia ini lansia masih mampu mentoleransi aktivitas sehari-hari yang bisa dilakukan sendiri namun semakin tua maka lansia akan membutuhkan bantuan orang lain untuk memenuhi kebutuhan sehariharinya. Penurunan kemampuan lansia dalam melakukan aktivitas sehari-hari terjadi seiring dengan bertambahnya umur. ${ }^{11}$ 


\section{Hubungan \\ Antara \\ Dukungan \\ Informasional dengan Kemandirian Lansia dalam Memenuhi Aktivitas Kehidupan Sehari-Hari}

Pada penelitian ini berdasarkan hasil uji statistik dengan menggunakan ChiSquare diperoleh adanya hubungan antara dukungan informasional terhadap kemandirian lansia dalam memenuhi aktivitas kehidupan sehari-hari. Pada suatu penelitian menemukan bahwa $79.4 \%$ keluarga memberikan dukungan instrumental kepada lansia. Keluarga menyediakan alat mandi, makan, pakaian lansia dan lain-lain, bukan berarti lansia menjadi tidak mandiri dengan disediakannya alat-alat tersebut, namun bagaimana kemandirian lansia dalam menggunakan alat-alat tersebut. ${ }^{12}$

Dukungan informasional merupakan dukungan keluarga yang meliputi jaringan komunikasi dan tanggung jawab bersama, termasuk di dalamnya memberikan solusi dari masalah, memberikan nasehat, pengarahan, saran, atau umpan balik tentang apa yang dilakukan oleh seseorang.

Dukungan informasional yang diberikan kepada lansia berupa informasi tentang perubahan fisik yang terjadi pada lansia. Dukungan informatif yang tepat akan meningkatkan kemandirian lansia dalam pemenuhan aktivitas sehari-hari. Lingkungan tempat tinggal di daerah perkotaan, memudahkan keluarga yang memiliki lansia untuk mencari informasi sebanyak-banyaknya mengenai perubahan pada lansia baik melalui media cetak seperti koran atau majalah maupun media elektronik seperti televisi dan internet serta fasilitas kesehatan yang lengkap di daerah perkotaan. ${ }^{13}$

Pada penelitian ini lansia yang menerima dukungan informasional yang baik dari kelurga membuat mereka menjadi mandiri dalam melakukan aktivitas sehari hari dimana keluarga selalu memberikan informasi tentang perubahan perubahan fisik yang terjadi pada lansia seiring dengan bertambahnya umur mereka. Keluarga juga selalu memberikan informasi tentang hal apa yang bisa dilakukan sendiri dan perlu bantuan orang lain misalnya ketika lansia sakit. Itu artinya kegiatan sehari hari tidak bisa dilakukan sendiri tetapi harus memerlukan bantuan orang lain. Keluarga juga selalu meningatkan lansia untuk ke posyandu setiap bulannya. Keluarga juga menasehati lansia yang memiliki jarak rumah yang tidak terlalu jauh dengan berjalan kaki yang merupakan olahraga yang dapat meningkatkan kesehatan lansia.

Berdasarkan hasil wawancara Pada lansia yang menerima dukungan informasional kurang namun memiliki kemandirian melakukan aktivitas sehari hari disebabkan karena lansia tersebut sering mencari tau tentang perkembangan fisiknya pada tenaga kesehatan baik lewat posyandu maupun penyuluhan yang dilaksanakan petugas kesehatan. Sehingga menyebabkan lansia dapat mandiri dalam melakukan kegiatan sehari hari.

\section{Hubungan Antara Dukungan Instrumental dengan Kemandirian Lansia dalam Memenuhi Aktivitas Kehidupan Sehari-Hari}

Pada penelitian ini berdasarkan hasil uji statistik diperoleh adanya hubungan antara dukungan instrumental terhadap kemandirian lansia dalam memenuhi aktivitas kehidupan sehari-hari.

Dukungan instrumental merupakan dukungan yang diberikan meliputi penyediaan dukungan jasmaniah seperti pelayanan, bantuan finansial dan material berupa bantuan nyata (instrumental support material support). Lansia mengalami banyak perubahan baik fisiologis maupun psikologis. Adanya perubahan fisiologis menyebabkan lansia membutuhkan bantuan dalam memenuhi kebutuhan sehari-hari. ${ }^{14}$

Tanda kemunduran fisik antara lain gigi mulai ompong, pendengaran dan penglihatan mulai kurang, mudah lelah, gerakan menjadi lamban dan kurang lincah dan perubahan fisik lainnya. ${ }^{15}$ Dukungan instrumental akan lebih efektif untuk keadaan kesukaran tenaga dan dana. ${ }^{16}$ Keluarga menyediakan alat mandi, makan, 
pakaian lansia dan lain-lain, bukan berarti lansia menjadi tidak mandiri dengan disediakannya alat-alat tersebut, namun bagaimana kemandirian lansia dalam menggunakan alat-alat tersebut. ${ }^{14}$

Berdasarkan hasil wawancara dalam penelitian ini diperoleh lansia yang menerima dukungan instrumental yang baik dan memiliki kemandirian dalam melakukan aktivitas sehari hari hal ini dikarenakan karena anggota keluarga yang selalu menyediakan kebutuhan lansia misalnya peralatan untuk makan dan minum serta peralatan untuk mandi. Selain itu keluarga juga selalu menyediakan pakaian yang akan dipakai namun tetap memberi kepercayaan pada lansia untuk memakainya secara mandiri. Namun ketika lansia tersebut mengalami kendala saat menggunakan pakaian keluarga tetap mendampingi dan membantu lansia. Hasil wawancara pada lansia yang menerima dukungan instrumental kurang namun memiliki kemandirian dalam melakukan aktivitas sehari hari disebabkan karena lansia tersebut memang sejak masih muda sudah terbiasa mandiri dalam melakukan aktivitas sehari hari tanpa bantuan orang lain kecuali saat mereka sakit. Sehingga ketika memasuki usia lanjutpun mereka tetap tidak tergantung pada orang lain.

\section{Hubungan Antara Dukungan Penilaian dengan Kemandirian Lansia dalam Memenuhi Aktivitas Kehidupan Sehari- Hari}

Pada penelitian ini berdasarkan hasil uji statistik diperoleh adanya hubungan antara dukungan penilaian terhadap kemandirian lansia dalam memenuhi aktivitas kehidupan sehari-hari.

Dukungan penilaian merupakan dukungan yang terjadi bila ada ekspresi penilaian yang positif terhadap seseorang. Individu mempunyai seseorang yang dapat diajak bicara tentang masalah mereka, yang dipercaya dan menjadi penyemangat serta memberikan dukungan atas ide-ide dan perasaannya.
Dukungan penghargaan terjadi lewat ungkapan hormat (penghargaan positif) atau pujian dan dorongan agar lansia mandiri dalam aktivitas sehari-hari. Dukungan penghargaan menyebabkan lansia merasa bahwa dirinya dianggap dan dihargai sehingga akan menaikkan harga diri dan meningkatkan kemandirian lansia dalam beraktivitas. ${ }^{16}$

Di Indonesia sudah menjadi budaya bahwa orang tua merupakan tempat meminta saran dan pertimbangan terhadap masalah yang terjadi di keluarga maupun di masyarakat. Dalam keluarga, kakek dan nenek mempunyai peranan sangat penting sebagai warga tertua yang penuh pengalaman dan kebijakan, namun tidak jarang lansia merasa tidak dibutuhkan lagi sehingga dukungan berupa penghargaan sangat penting bagi lansia. ${ }^{17}$

Dari hasil penelitian ini diperoleh bahwa lansia yang menerima dukungan penilaian yang baik memiliki kemandirian dalam beraktivitas. Hal ini dikarenakan lansia tersebut memperoleh penghargaan dari keluarga dalam beraktivitas misalnya makan dan minum, membersihkan diri sehingga membuat lansia menjadi percaya diri dalam melakukan aktivitas.

Ketika seseorang memasuki masa lanjut usia (lansia), maka dukungan keluarga dari orang lain menjadi sangat berharga dan akan menambah ketenteraman hidupnya. Pemicu lansia tergantung pada orang lain adalah menurunnya fungsi fisiologis dimana hal ini akan berdampak pada status dan derajat kesehatannya. Walaupun demikian, dengan dukungan keluarga itu tidaklah berarti bahwa setelah memasuki masa lansia orang hanya tinggal duduk, diam, tenang, dan berdiam diri saja. Untuk menjaga kesehatan fisik maupun kejiwaannya, lansia justru tetap harus melakukan aktivitasaktivitas yang berguna bagi kehidupannya. ${ }^{18}$

Lansia tak boleh membiarkan semua kebutuhannya dilayani oleh orang lain. Hal itu justru akan mendatangkan berbagai penyakit dan penderitaan, sehingga bisa menyebabkan para lansia cepat meninggal dunia. Dalam rangka membantu agar lansia 
tetap dapat beraktivitas, maka dibutuhkan dukungan sosial dari keluarga. dukungan keluarga merupakan bantuan atau dukungan yang diterima individu dari orang-orang tertentu dalam kehidupannya dan berada dalam lingkungan sosial tertentu yang membuat si penerima merasa diperhatikan, dihargai dan dicintai.

Dukungan keluarga dapat membantu individu untuk mengatasi masalahnya secara efektif. Dukungan keluarga juga dapat meningkatkan kesehatan fisik dan mental pada lansia. Dukungan keluarga berhubungan dengan pengurangan gejala penyakit dan kemampuan untuk memenuhi kebutuhannya sendiri akan perawatan kesehatan. $^{19}$

Keluarga mempunyai peran penting dalam menunjang kemandirian usia lanjut. Karena keluarga memiliki kedekatan dan keterikatan baik fisik maupun emosional. Ketidakmandirian lansia disebabkan tiga hal yaitu keterbatasan fisik dan atau mental, memilih untuk dibantu dalam satu aktivitas tertentu namun mandiri dalam aktivitas lainnya, serta tidak adanya dukungan keluarga. ${ }^{20}$

Dukungan keluarga dalam memelihara dan memotivasi nilai positif kehidupan serta meningkatkan perilaku kesehatan yang baik menjadi semakin penting. Dukungan keluarga yang optimal mendorong kesehatan para lansia meningkat, selain itu kegiatan harian para lansia menjadi teratur dan tidak berlebihan. Bagian dari dukungan sosial adalah cinta dan kasih sayang yang harus dilihat secara terpisah sebagai. $^{21}$ Bagian dari dukungan sosial adalah cinta dan kasih sayang yang harus dilihat secara terpisah sebagai bagian asuhan dan perhatian dalam fungsi efektif keluarga. ${ }^{22}$

Dengan demikian dukungan keluarga sangat berhubungan dalam mendukung kemandirian lansia untuk menjaga kesehatan fisik maupun kejiwaannya. Sehingga meningkatkan kesehatan dan kualitas hidup lansia. Para lansia akan dapat menikmati hari tua mereka dengan tentram dan damai yang pada akhirnya akan memberikan banyak manfaat bagi semua anggota keluarga yang lain.

\section{KESIMPULAN}

Berdasarkan penelitian yang telah dilakukan, terdapat hubungan antara dukungan emosional, dukungan instrumental, dukungan penilaian, dan dukungan informasional dengan kemandirian lansia dalam memenuhi aktivitas kehidupan sehari-hari di Desa Tonusu Kecamatan Pamona Puselemba Kabupaten Poso.

\section{UCAPAN TERIMA KASIH}

Penulis Mengucapkan terima kepada semua pihak terutama STIKES Husada Mandiri Poso yang banyak berperan dalam pendanaan penelitian ini.

\section{DAFTAR PUSTAKA}

1. Pratikwo, S. Analisis pengaruh faktor nilai hidup, kemandirian, dan dukungan keluarga terhadap perilaku sehat lansia di Kelurahan Medono Kota Pekalongan. Jurnal Promosi Kesehatan Indonesia. 2006. Vol. 1 / No. 2.

2. United Nations. World population prospect : The 2015 revision. 2015. Diakses melalui http://www.un.org/en/development/desa /population/publications/pdf/ageing/ WPA_Report.pdf

3. Depkes RI. Riset Kesehatan Dasar. Jakarta: Badan Penelitian dan pengembangan Kesehatan Kementrian Kesehatan RI. 2013.

4. Setiabudhi, T. \& Hardywinoto. Panduan Gerontologi Tinjauan dari Berbagai Aspek: Menjaga Keseimbangan Kualitas Hidup Para Lanjut Usia. Jakarta: Gramedia Pustaka Utama. 2005.

5. Stanley, M., \& Beare, P. G. Buku Ajar Keperawatan Gerontik. Jakarta: EGC. 2006.

6. Watson, Roger. Perawatan Pada Lanjut Usia. Jakarta: EGC. 2003. 
7. Dewi. Hubungan dukungan keluarga dengan kemampuan aktifitas seharihari lansia di Kota Semarang. Universitas Indonesia, Fakultas Ilmu Keperawatan. Skripsi. 2011. http://lontar.ui.ac.id/opac/themes/green/ detail2.jsp?id=20281681\&lokasi=l.okal, diakses pada tanggal 13 Juli 2021

8. Purba, Johana, dkk. Pengaruh dukungan Sosial terhadap Burnout pada Guru. Jurnal Psikologi. No. 2. 2007. Vol. 5. 77-87

9. Kuntjoro, Z.S. Masalah Kesehatan Jiwa Lansia. 2007. Diakses dari http://www.epsikologi.com/usia/160402

10. Hardywinoto., \& Setiabudhi. Menjaga Keseimbangan Kualitas Hidup Para Lanjut Usia, Panduan Gerontology, Tinjauan dari Berbagai Aspek. Jakarta : Gramedia Pustaka Utama. 2005.

11. Azizah, Lilik Ma'rifatul. Keperawatan Lanjut Usia. Yogyakarta : Graha Ilmu. 2011.

12. Khulaifah, Siti., Haryanto, Joni., Nihayati, Hanik Endang. Hubungan Dukungan Keluarga Dengan Kemandirian Lansia Dalam Pemenuhan Activitie Daily Living Di Dusun Sembayat Timur, Kecamatan Manyar, Kabupaten Gresik. 2011. https://ejournal.unair.ac.id/IJCHN/article/view/1 1946

13. Soejono, czeresna Heriawan. Belum Memadai fasilitas bagi warga usia lanjut. http://www.kompas.com/kompas cetak/0203/25/iptek/pert.10.htm. 2002.
14. Darmojo \& Martono, Buku Ajar Geriatri (Ilmu Kesehatan Usia Lanjut). FKUI: Jakarta, 9, 22. 2004.

15. Nugroho, W. Keperawatan Gerontik \& Geriatrik, Edisi-3. Jakarta:EGC. 2008.

16. House \& Smett. Psikologi Kesehatan, EGC, Jakarta. 2002.

17. Murodion, W. Lansia harus tetap bergairah hidup sehat. Jakarta: Depkes RI. 2006.

18. Kuntjoro, S. Dukungan Sosial Buat Lansia.

http://www.balipost.co.id.balipostcetak/ 2006/5/7/kel 3.html. 2002.

19. Psychemate. Self efficacy diakses melalui: http:// Psychemate.Blogspot.com. 2007.

20. Harnilawati. Konsep dan proses Keperawatan Keluarga. Sulawesi Selatan: Pustaka As Salamm. 2013.

21. Pratikwo, S., Pietojo, H., \& Widjanarko, B. Analisis Pengaruh Faktor Nilai Hidup, Kemandirian, Dan Dukungan Keluarga Terhadap Perilaku Sehat Lansia Di Kelurahan Medono Kota Pekalongan. Jurnal Promosi Kesehatan Indonesia, 2006. 1(2), 13-22. http://ejournal.undip.ac.id/index.php/jpk $\mathrm{i} /$ article/view/2822.

22. Sampelan, I., \& Kun, R. Hubungan Dukungan Keluarga Dengan Kemandirian Lansia Dalam Pemenuhan Aktivitas Sehari-Hari Di Desa Batu Kecamatan Likupang Selatan Kabupatten Minahasa Utara. EJournal Keperawatan, 2015. 3(2), 1-7. https://doi.org/10.1117/12.88554 